\title{
ASEPTIC MENINGITIS BY ECHOVIRUS 30 IN SÃO PAULO STATE, BRAZIL
}

\author{
Bráulio Caetano Machado; Raquel de Souza Ferreira; Rita de Cássia Compagnoli Carmona; \\ Maria do Carmo Sampaio Tavares Timenetsky
}

Instituto Adolfo Lutz, Virologia, Laboratório de Vírus Entéricos, São Paulo, SP, Brasil

Submitted: April 20, 2006; Returned to authors for corrections: June 29, 2006; Approved: October 13, 2006

\begin{abstract}
The objective of this study was to identify and characterize the immunological and molecular aspects of Human Enterovirus (HEV) associated with aseptic meningitis cases in São Paulo State, Brazil. Clinical samples (cerebrospinal fluid CSF, stool and sera) were analyzed from 21 viral meningitis suspected cases collected in the period from 1998 to 1999. The isolated virus were identified as belonging to Enterovirus genus and specifically to echovirus serotype 30 (EV-30), using immunological techniques as Indirect Immunofluorescense Assay (IFA) and Neutralization (Nt) and by molecular technique of Reverse Transcription Polymerase Chain Reaction (RT-PCR) directed to the 5 ${ }^{\circ} \mathrm{NTR}$ and VP1 regions of viral genome. The results obtained contributed with to the surveillance system of São Paulo State and they are important due to a shortage of epidemiological data about the circulation of EV-30 associated to aseptic meningitis in this region of the world.
\end{abstract}

Key words: Enterovirus, viral meningitis, molecular and immunological diagnosis, RT-PCR for Enterovirus, indirect imunnofluorescense assay

\section{INTRODUCTION}

Aseptic meningitis is a central nervous system infection occurring sporadically, and as outbreaks, presenting more than $90 \%$ of cases with an identified cause associated with enteroviruses (31). Human Enterovirus (HEV) is a RNA positive single stranded virus in the Picornaviridae family, constituted of five species grouped into (HEV-A, $-B,-C,-D$ and Poliovirus) clusters. The $H E V-\mathrm{B}$ cluster includes coxsakievirus B (CV-B), coxsackievirus A9 (CV-A9), enterovirus 69 (HEV-69), and all echoviruses (EV) (29).

Although most of $H E V$ infections cases are asymptomatic or result in mild febrile illnesses, aseptic meningitis is predominantly reported. The $H E V$ strains most frequently isolated from patients with aseptic meningitis are EV-30, EV-6, EV-11, and EV-9 (6).

Analyzing notified meningitis cases in the period from 1979 to 1999 in São Paulo State, Brazil, we observed a high incidence of meningitis cases without determined etiology, and among them, $50 \%$ to $60 \%$ of probable viral etiology (10).
In 1998 an increase of aseptic meningitis cases was observed in the city of São Paulo with a total of 101 notified cases until October denoting an outbreak in progress.

Laboratory data (CSF cerebrospinal fluid, cytochemical diagnosis) and epidemiological surveillance of the cases indicated viral association and other arising of another outbreaks were further observed in several cities of São Paulo State. (CVE, unpublished data, 1998). These data demonstrated the need for research of viral agents associated to non-bacterium meningitis in our region.

With the objective to investigate the etiological viral agent of new suspected cases and to perform this characterization, we received samples of 21 patients from different affected regions of the State. The evaluation of laboratory results obtained was made with epidemiological relationship of the cases and the clinical diagnosis from medical services of these regions.

Molecular methods for $H E V$ detection are increasingly becoming available $(30,31)$. Serotype-specific PCR (Polymerase Chain Reaction) primers have been developed by CDC (Centers

*Corresponding Author. Mailing address: Instituto Adolfo Lutz, Virologia, Laboratório de Vírus Entéricos, Av. Dr. Arnaldo, 355 - CEP 01246-902, São Paulo, SP, Brasil. Tel.: (11) 3068-2909. E-mail: bcmachado@ial.sp.gov.br 
for Disease Control and Prevention, USA) for several enteroviruses, including EV-30 (15). These serotype-specific primers are useful for rapid differentiation of outbreak strains from sporadic infections with other enteroviruses.

In the present study we describe the immunological and molecular characterization of $H E V$ isolates obtained from viral meningitis suspected cases collected in the period of the outbreak, from November 1998 to February 1999.

\section{MATERIALS AND METHODS}

\section{Clinical Samples}

Case definition of aseptic meningitis was based on clinical and cerebrospinal fluid (CSF) findings compatible with viral meningitis and tested negative for other pathogens.

Stool, and CSF samples from 21 patients with clinically suspected aseptic meningitis were sent for viral diagnostic. Sera samples from acute and convalescent phase were also collected in 11 cases to perform antibody seradiagnosis.

\section{Viruses}

Virus prototype strains (EV-30 and EV-4) were obtained from the American Type Culture Collection - ATCC (Rockville, Md.) and $H E V$ isolates from clinical samples maintained in our laboratory.

\section{Viral culture}

The samples were collected in sterile containers, and transported to laboratory adequately at $-195^{\circ} \mathrm{C}$ (liquid nitrogen) for $\mathrm{CSF}$ and $0^{\circ} \mathrm{C}$ to $4^{\circ} \mathrm{C}$ for stool and sera in expanded polystyrene boxes. CSF was cultured without treatment, and stool samples were prepared with $10 \%$ suspension in phosphate-buffered saline (PBS) following 60 minutes at 10,000 X g centrifugation, and the addition of $0.1 \mathrm{mg}$ of antibiotic solution (penicillin and streptomycin, at final concentration of $50 \mu \mathrm{g}$ per $\mathrm{mL}$ ), to the supernatant. The inoculum was stored at $-70^{\circ} \mathrm{C}$ and inoculated in cell culture. Viruses were propagated in Vero (green monkey kidney) ATCC-CCL-81, RD (human rabdomyosarcoma) ATCCCCL-136, and HEp-2 (human larynx carcinoma) ATCC-CCL-23 cell monolayer cultures. These cultures were inoculated with a minimum of $0.1 \mathrm{~mL}$ of specimen and after 30 minutes of adsorption, were maintained in Eagle L15 medium incubated at $37^{\circ} \mathrm{C}$ in bacteriologic incubator. The cells were observed daily for the presence of viral cytopathogenic effect (CPE) $(8,21)$.

\section{Indirect Immunofluorescence Assay}

Positive cell cultures were harvested when $75 \%$ of cytopathogenic effect was attained. Cell supernatant was centrifuged at 3,000 X g for 15 minutes, then discharged and the cell pellet was seeded onto slides, dried, and fixed in cold acetone at $4^{\circ} \mathrm{C}$. Monoclonal antibodies (Mabs) (Chemicon Inc., Temucula, CA) directed to Enterovirus (genus, group and serotypes) and a goat anti-mouse IgG antibody conjugated with fluorescein isothiocyanate were used according to the manufacturer's instructions. Incubations were performed at $37^{\circ} \mathrm{C}$ for 30 minutes in a moist chamber. After being washed in PBS, the slides were mounted with buffered glycerin and observed under UV light with an epi-fluorescence microscope at a magnification of X 400 (3).

\section{Neutralization test $(\mathbf{N t})$}

Serotyping was carried out using a neutralization method with the use of intersecting pools of antisera A to $\mathrm{H}$ (Statens Serum Institut, Copenhagen, Denmark) against the titulated virus, $100 \mathrm{TCD}_{50}$, by Reed Muench method (28) according to the Lim-Benyesh-Melnick (LBM) scheme for identification (19). Individual antisera against coxsackievirus B3 (CV-B3) was also included.

\section{Primers}

PCR primers were selected from highly conserved regions of the 5'NTR (nontranslated region): ENV-AS1 anti-sense (5'-ATTGTCACCATAAGCAGCCA-3') and ENV-S1 sense (5'-CAAGCACTTCTGTTTCCCCGC-3') for characterization of Enterovirus genus (ROTBART, H. A. 1990). To characterize echovirus serotype 30, primers directed to VP1, EV-30 P1 (5'TCCGCGTGCAACGATTTCTC-3') and EV-30 P2 (5' CTCCCACACGCAGTTCTGCC-3') were selected respectively (2).

\section{RNA extraction and in house RT-PCR}

Viral RNA was extracted from infected cell culture supernatant with Trizol LS (Invitrogen) according to the manufacturer's instructions. Reverse transcription-PCR (RTPCR) was carried out by a single-step method. In the assay the reverse transcription and molecular amplification steps are combined through as described previously with some modifications (2). To $5 \mu \mathrm{L}$ of the RNA was added $45 \mu \mathrm{L}$ of the RT-PCR mixture containing 10x PCR buffer (TRIS-HCl $100 \mathrm{mM}$, $\mathrm{KCl} 500 \mathrm{mM}$, Triton X-100 1\%), $\mathrm{MgCl}_{2}(25 \mathrm{mM})$, mixture of dNTP (1.25 mM each dATP, dGTP, dCTP, dTTP), pool of primers (AS1 -S1 or EV-30 P1 -EV-30 P2, $20 \mu \mathrm{M} / \mu L$ each); Taq DNA polymerase (2.5 U/ $\mu \mathrm{L})$, Super Script II Reverse Transcriptase $(1 \mathrm{U} / \mu \mathrm{L}$, Invitrogen Life Technologies), RNAsin (40,000 U/mL, Pharmacia), and $\mathrm{H}_{2} \mathrm{O}$. The mixture was incubated in thermocycler (Perkin Elmer 9600) for 60 minutes at $42^{\circ} \mathrm{C}$, and followed by 25 cycles $(1$ minute at $94^{\circ} \mathrm{C}, 2$ minutes at $50^{\circ} \mathrm{C}$, and 1 minute at $72^{\circ} \mathrm{C}$ ). Following this process, $5 \mu \mathrm{L}$ of the PCR products were subjected to electrophoresis in $1.5 \%$ agarose gels (Ultra Pure, Invitrogen) in TBE buffer (Tris, boric acid, EDTA) containing Ethidium Bromide $(0.5 \mu \mathrm{g}$ per $\mathrm{mL})$, and was run for 50 minutes at $150 \mathrm{~V}$. PCR products were photographed under UV light. Amplicons of $437 \mathrm{bp}$ and $900 \mathrm{bp}$ were amplified from each viral cDNA, using primers for 5'NTR and for VP1 regions, respectively (30). 


\section{Antibody titration in paired sera}

For serological diagnosis, paired sera samples were required. This microneutralization technique was applied for detection of antibodies against the prototype antigen (EV-30). To perform the test, serial dilutions from 1:8 to $1: 1024$ (two fold) of the paired sera, were mixed to the antigen $(100 \mathrm{TCD} 50 / 0.1 \mathrm{~mL})$ and incubated for 2 hours at $37^{\circ} \mathrm{C}$. After the incubation period, 100 $\mu \mathrm{L}$ of $\mathrm{RD}$ cell suspension $(220,000$ cells per $\mathrm{mL}$ ) was distributed into the wells. Microplates were incubated for 72 hours $\left(37^{\circ} \mathrm{C}\right)$ and observed on the inverted microscope for viral infectivity neutralization. The increase of $4 \mathrm{x}$ in the antibody titer was considered indicator of seraconversion (21).

\section{Ethical Aspects}

This study was submitted to the Ethical Research Committee of the Adolfo Lutz Institute and was approved.

\section{RESULTS}

Twenty-one suspect viral meningitis cases from several regions of São Paulo State were studied. Eighteen CSF samples, 14 stools samples and 11 paired sera samples were analyzed. The results obtained are presented in Table 1 .

The isolated viruses were identified as Enterovirus, echovirus serotype 30 , in $62 \%$ (13/21) of the studied cases.

Viral isolates were observed after 2 passages in RD cell line. Virus culture from CSF was obtained after the first or second passage in cell culture; virus culture from stool needed one more passage due to anti-cell toxicity, even with treatment of stool material. $H E V$ were isolated in $44 \%$ (8/18) of CSF samples and in 57\% (8/14) of stool samples. No other virus was isolated from the different cell lineages used.

Table 1. Results from virus isolation, IFA, Nt, RT-PCR, and seraconversion of 21 patients with aseptic meningitis during a summer outbreak, in São Paulo State, 1998-1999.

\begin{tabular}{|c|c|c|c|c|c|c|c|c|c|c|}
\hline \multirow[t]{3}{*}{ Patient } & \multicolumn{3}{|c|}{ Material } & \multicolumn{2}{|c|}{ Virus Isolated } & \multicolumn{4}{|c|}{ Characterization } & \multirow{3}{*}{$\begin{array}{c}\text { NtSeraconversion } \\
\text { to EV30 }\end{array}$} \\
\hline & \multirow[b]{2}{*}{ CSF } & \multirow[b]{2}{*}{ Stools } & \multirow[b]{2}{*}{ Sera $^{4}$} & \multirow[b]{2}{*}{ CSF } & \multirow[b]{2}{*}{ Stools } & \multirow[t]{2}{*}{ IFA } & \multirow[t]{2}{*}{$\mathrm{Nt}$} & \multicolumn{2}{|c|}{ RT-PCR } & \\
\hline & & & & & & & & 5'NTR & VP1 & \\
\hline 1 & & $\mathrm{x}$ & $\mathrm{x}$ & & + & EV30 & EV30 & HEV & E30 & $\oplus$ \\
\hline 2 & & $\mathrm{x}$ & $\mathrm{x}$ & & + & EV30 & Ev30 & HEV & E30 & $\oplus$ \\
\hline 3 & $\mathrm{x}$ & $\mathrm{x}$ & $\mathrm{x}$ & + & + & EV30 & EV30 & HEV & E30 & $\oplus$ \\
\hline 4 & $\mathrm{x}$ & & & + & & EV30 & EV30 & HEV & E30 & \\
\hline 5 & $\mathrm{x}$ & & & $\mathrm{N}$ & & & & & & \\
\hline 6 & $\mathrm{x}$ & $\mathrm{x}$ & $\mathrm{x}$ & $\mathrm{N}$ & + & EV30 & EV30 & $\mathrm{HEV}$ & E30 & $\oplus$ \\
\hline 7 & $\mathrm{x}$ & $\mathrm{x}$ & & $\mathrm{N}$ & $\mathrm{N}$ & & & & & \\
\hline 8 & $\mathrm{x}$ & & $\mathrm{x}$ & + & & EV30 & EV30 & $\mathrm{HEV}$ & E30 & $\oplus$ \\
\hline 9 & $\mathrm{x}$ & & & $\mathrm{N}$ & & & & & & \\
\hline 10 & $\mathrm{x}$ & & & $\mathrm{N}$ & & & & & & \\
\hline 11 & $\mathrm{x}$ & $\mathrm{x}$ & $\mathrm{x}$ & + & $\mathrm{N}$ & EV30 & EV30 & $\mathrm{HEV}$ & E30 & $\oplus$ \\
\hline 12 & $\mathrm{x}$ & $\mathrm{x}$ & $\mathrm{x}$ & $\mathrm{N}$ & + & EV30 & EV30 & $\mathrm{HEV}$ & E30 & $\oplus$ \\
\hline 13 & $\mathrm{x}$ & & & $\mathrm{N}$ & & & & & & \\
\hline 14 & $\mathrm{x}$ & $\mathrm{x}$ & $\mathrm{x}$ & + & + & EV30 & EV30 & $\mathrm{HEV}$ & E30 & $\oplus$ \\
\hline 15 & $\mathrm{x}$ & $\mathrm{x}$ & $\mathrm{x}$ & + & + & EV30 & EV30 & $\mathrm{HEV}$ & $\mathrm{E} 30$ & $>$ Title to isolated \\
\hline 16 & $\mathrm{x}$ & & $\mathrm{x}$ & + & & EV30 & EV30 & $\mathrm{HEV}$ & $\mathrm{E} 30$ & $\oplus$ \\
\hline 17 & $\mathrm{x}$ & $\mathrm{x}$ & & $\mathrm{N}$ & $\mathrm{N}$ & & & & & \\
\hline 18 & $\mathrm{x}$ & $\mathrm{x}$ & & + & $\mathrm{N}$ & EV30 & EV30 & $\mathrm{HEV}$ & E30 & \\
\hline 19 & & $\mathrm{x}$ & $\mathrm{x}$ & & + & EV30 & EV30 & $\mathrm{HEV}$ & E30 & $\oplus$ \\
\hline 20 & $\mathrm{x}$ & $\mathrm{x}$ & & $\mathrm{N}$ & $\mathrm{N}$ & & & & & \\
\hline 21 & $\mathrm{x}$ & $\mathrm{x}$ & & $\mathrm{N}$ & $\mathrm{N}$ & & & & & \\
\hline Total & 18 & 14 & 11 & 8 & 8 & 16 & 16 & 16 & 16 & 11 \\
\hline
\end{tabular}

4= paired sera $+=$ positive isolation; $\mathrm{N}=$ negative isolation; $\mathrm{EV}=$ Enterovirus; $\mathrm{EV} 30$ = echovirus serotype 30.; IFA = Indirect Imunofluorescence.; $\mathrm{Nt}=$ Neutralization; PCR $=$ Polymerase Chain Reaction: region 5'NTC and region VP1.; $\oplus=$ seraconversion; > = antibody titer to the isolated virus (EV30). 
Of the total 11 cases with paired sera samples, 10(91\%) presented significant conversion in the antibody titer for the respective prototype strain (EV-30) and 1 case presented the same antibody titer in both samples collected in the acute and convalescence phases. Subsequently, these paired sample presented considerable seraconversion for the isolated virus (EV-30) originated from another case of the outbreak.

By IFA technique, 16 viral isolates were identified as Enterovirus genus, echovirus group and EV-30 serotype. Two isolates presented cross-reaction to specific monoclonal antibody for EV-4 serotype. These isolated viruses were neutralized by CEG pools of (LBM) specific sera for $H E V$ and were identified as EV-30 by Neutralization (Nt).

Using PCR test, all isolates were genotyped as Enterovirus genus, presenting cDNA amplicons of $437 \mathrm{bp}$ for the region 5'NTC, and as EV-30 serotype presenting amplicons of 900bp for the VP1 region. The specific primers for the VP1 region used in this study did not amplify the EV-4 prototype virus. Figs. 1 and 2.

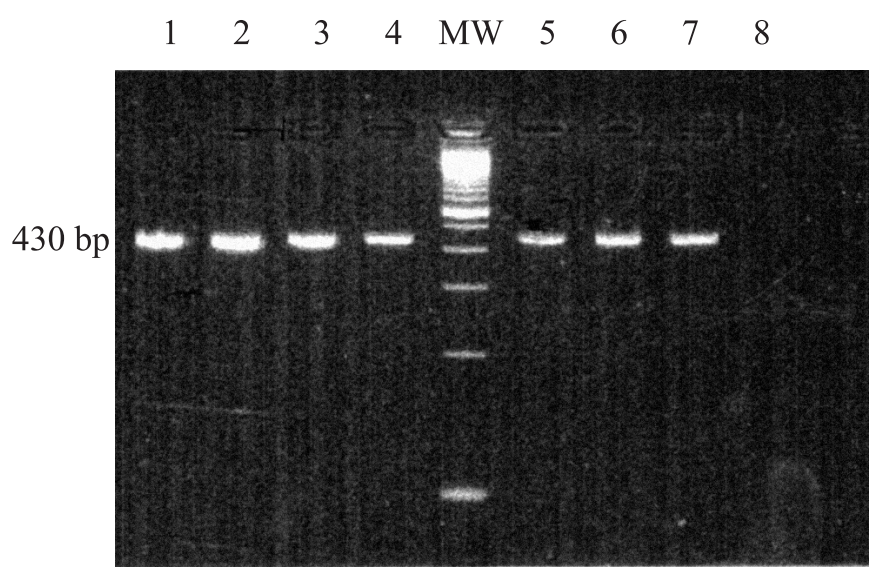

$100 \mathrm{bp}$

Figure 1. RT-PCR to the 5'NCR region of the Enterovirus isolated in cell cultures; Lanes 1,2,3,4,5,6,7 - amplification product 430bp; lane 8 - negative control; molecular weight (MW) 100bp.

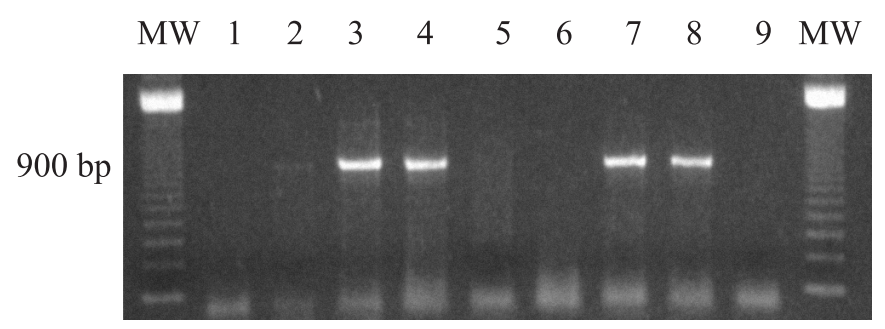

Figure 2. RT-PCR to the VP1 region of the Enterovirus, EV30 samples. Lanes 2, 3, 4, 7, 8 - amplification products 900 bp; lanes 5 and 6 EV4 samples; lanes 1 and 9 -negative control; molecular weight (MW) $123 \mathrm{bp}$.

\section{DISCUSSION}

In this study we describe the identification and characterization of $H E V$ isolates during an outbreak of aseptic meningitis in São Paulo State, Brazil.

The isolated viruses during in this period were identified as Enterovirus genus, echovirus group and EV-30 serotype using, both, molecular and immunological techniques.

Analyzing our laboratory results associated with epidemiological data and clinical diagnosis information of each case, we conclude that Enterovirus EV-30 was the etiological agent involved in the outbreaks in the State of São Paulo.

This study points out a period of increase of viral meningitis cases in the State of São Paulo according to epidemiological studies of CVE. For this period (1998 and 1999) the incidence was 17,00/100.000 [cases per inhabitants] and the incidence media for viral meningitis for the last 15 years (1990 to 2005) was $11,74 / 100.000(27)$.

The result signs the importance of echovirus serotype 30 association in aseptic meningitis cases adding new data collected in this region of the world, which is characterized by rather poor information about HEV circulation. In Brazil we have few articles related to EV-30 meningitis $(16,32)$. The circulation of echovirus, specifically echovirus 30 is fully worldwide related nowadays.

During the period from 1970 to 2001, in the USA, EV-30 was among the 15 enteroviruses most commonly reported each year, accounting for $8.2 \%$ of all enteroviruses isolates reported to CDC (CDC, unpublished data, 2003). The increase of aseptic meningitis associated with high activity of EV-9 and EV-30 is consistent with the historical data; during 1998 and 1999, the peak years for viral meningitis hospitalizations in the United States coincided with periods of high activity of either EV-9 or EV-30 (6). In Spain a study reported cases associated to viral meningitis, during the period from 1988 to 1997 with a high incidence of $H E V$ and the predominance of EV-30 (90\%) among non-polio serotype (36). This serotype was responsible for aseptic meningitis epidemics in Japan in 1991 and 1997 (39, 40), Switzerland in 1996 (13), Canada in 1998 (4), Romania in 1999 (5), and more recently published, in Turkey in 1999 (26), France in 2000 (7), Belgium in 2000 (35) and Brazil in 2003 $(16,2)$. Our retrospective study agrees with literature data.

Isolation of $H E V$ from affected organs and from body fluids (e.g.:CSF), gives the strongest evidence for $H E V$ infection $(9,22)$. However, stool sample is the most sensitive for $H E V$ detection in cell culture due to more amount of viral particles excretion in a 30 day period (38).

Although viral isolation in cell culture is often being used as a gold standard for $H E V$ identification, the technical procedures and information about viral isolation could vary considerably between laboratories $(11,18)$.

In this study, three types of cell lineages were used. They were susceptible to isolation of the most viruses associated to 
neurological disease. All echovirus serotype 30 were isolated in RD cell culture, according to literature data (14).

The etiology of meningitis cases was determined by detection of virus in CSF in stool and antibody titer conversion for isolated virus in cases which we had stool material isolation only.

Identification of $H E V$ in CSF defines the agent, but, on the other hand, the isolation of virus in stool needs antibody titration of the patient's paired sera to confirm the viral etiology. This study demonstrated the importance of seraconversion and virus isolation from stools samples to confirm the etiology in five cases with stool positive cultures. Sub clinical infections are very common due to a frequent exposure to $H E V$ and the results could be confused.

The introduction of IFA allowed serotyping of isolated virus with reducing of time and brought agility to the release of results; but, it is important to note that, IFA can present, in some cases, false negative results. Some viral strains can present low affinity to a specific monoclonal antibody due to mutations leading to antigenic changes in the target epitope occurring, therefore, not recognition by monoclonal antibody (3). Specific MAb directed to EV-4 can present low cross-reaction with EV-30, EV6 and EV-11 MAbs $(3,16)$. In our study cross-reaction between EV-4 and EV-30 MAbs was observed in 2 samples. Serotypes were defined in complementary tests, $\mathrm{Nt}$ and PCR.

The virus was identified as echovirus serotype 30 by Neutralization (Nt) (17), the gold standard method to $H E V$ identification. Antigenic changes among $H E V$ serotypes can cause difficulties in identification by traditional Nt test $(37,38)$.

Although serotyping may in general be of limited importance for the management of patients with an $H E V$ infection, it is essential to understand the epidemiology of $H E V$ for monitoring the emergence of new serotypes or possible changes in virulence, allowing previous and fast detection of new variants $(12,34)$.

The choice of PCR testing has been increasing for $H E V$ infection diagnosis, particularly for patients with aseptic meningitis. It has been demonstrated to be more sensitive than viral isolation, with 30 to $100 \%$ more of positive results $(1,30,33,41)$.

On the other hand, the use of cell culture promotes viral replication and increase of viral mass allowing the serotyping process through IFA and Nt.

In our study the use of PCR test for the 5' NTR region demonstrated to be of great utility, for viral identification after the first passage in cell culture increasing the sensitivity of viral detection and decreasing the time of detection. The 5'NTR region sequence presents high grade of homology for almost all $H E V$ and therefore, PCR amplification of this region was carried out to identify Enterovirus genus.

Early etiologic diagnosis of aseptic meningitis helps to avoid unnecessary antibiotic treatment and additional testing.

Correlation between VP1 and serotype has been demonstrated by comparison of VP1 gene sequences of all $\mathrm{HEV}$ prototypes (24). Sequences of the VP1 region from isolated virus have been analyzed to genomic comparison with $\mathrm{HEV}$ detected worldwide. Serotype-specific PCR developed for molecular typing of EV-30 isolates had become a rapid molecular biology-based typing method available (23). Adoption of this technique for identification allowed to clarify cases of crossreaction observed between EV-30 and EV-4 and the reduction of time for laboratory diagnosis.

Molecular diagnosis directed to VP1 target gives typing results corresponding to serotype determined by IFA and $\mathrm{Nt}$ with type-specific antisera (24). Sequencing isolates with generic primers that amplify all HEV serotypes has been established as a new and useful tool for molecular typing (25). These new primers successfully amplified HEV isolates of all 64 serotypes. When compared with Nt or IFA this test provides more advantages for a wide-ranging serotype investigation.

Molecular results confirm the EV-30 as etiological agent of the cases concluding our studies and contributing with epidemiological data about EV circulation in viral meningitis outbreaks at the region of São Paulo State, Brazil.

\section{ACKNOWLEDGMENTS}

We would like to thank the staff of the Cellular Cultures Section of Adolfo Lutz Institute for providing the cells used in this study. Rubia Anita Ferraz Santana and Denise Hage Russo for the intense collaboration and motivation on this work.

\section{RESUMO}

\section{Meningite asseptica por echovírus 30 no estado de São Paulo, Brasil}

O objetivo deste estudo foi identificar e caracterizar quanto aos aspectos imunológicos e moleculares os Enterovirus humanos associados a casos de meningite asséptica. Amostras clínicas (líquido cefaloraquidiano, fezes e soro) originárias de 21 casos suspeitos de meningite viral, provenientes do estado de São Paulo no período de 1998 a 1999 foram analisadas. Os vírus isolados foram identificados como pertencentes ao gênero Enterovirus e mais especificamente ao sorotipo echovírus 30 (EV-30), utilizando-se técnicas imunológicas como Imunofluorescência Indireta e Neutralização e técnica molecular da transcrição reversa - reação em cadeia da polimerase (RT-PCR) direcionada para as regiões 5' não traduzida (5'NTR) e Proteína Viral 1(VP1) do genoma viral. Os resultados obtidos contribuíram com o sistema de vigilância epidemiológica do estado de São Paulo na geração de informações sobre a circulação de EV-30 associado à meningite asséptica nessa região do mundo.

Palavras-chave: Enterovirus, meningite viral, diagnóstico imunológico e molecular, RT-PCR para Enterovirus, imunofluorescência indireta 


\section{REFERENCES}

1. Abzug, M.J.; Keyserling, H.L.; Lee, M.L.; Levin, M.J.; Rotbart, H.A. (1995). Diagnosis of neonatal Enterovirus infection by polymerase chain reaction. J. Pediatr., 126, 447-450.

2. Bailly, J.L.; Chambon, M.; Henquell, C.; Icart, J.; Peigue-Lafeuille, H. (2000). Genomic variations in echovirus 30 persistent isolates recovered from a chronically infected immunodeficient child and comparison with the reference strain. J. Clin. Microbiol., 38, 552557.

3. Bastis, D.S.; Simonet, S.; Patterson, M.A.; Neill, S. (1995). Identification of enteroviruses by indirect immunofluorescence using monoclonal antibodies. Clin. Diagn. Virol., 3, 83-93.

4. CCDR (Canada Communicable Disease Report). (1998). Outbreak of echovirus 30 meningitis in southern Saskatchewan. Health Canada, Vol. 24-23, December.

5. CDC (Centers For Disease Control And Prevention). (2000). Outbreak of aseptic meningitis associated with multiple Enterovirus serotypes - Romania 1999. Morbid. Mortal. Wkly. Rep., 49, 669671.

6. Cheshier, R.; Tu, E.; Glaser, C.; Bryant, K.; Arnold, K.; Carter, K.; Brenner, E.; Montgomery, S.P.; LaMonte, A.; Khetsuriani, N.; Pallansch, M. (2003). Outbreaks of aseptic meningitis associated with echoviruses 9 and 30 and preliminary surveillance reports on Enterovirus activity - United States, 2003. Morbid. Mortal. Wkly. Rep., 52(32), 761-764.

7. Chomel, J.J.; Antona, D.; Thouvenot, D.; Lina, B. (2003). Three echovirus serotypes responsible for outbreak of aseptic meningitis in Rhône-Alpes Region, France. Eur. J. Clin. Microbiol. Infect. Dis., 22, 191-193.

8. Chonmaitree, T.; Ford, C.; Sanders, C.; Lucia, H.L. (1988). Comparison of cell cultures for rapid isolation of enteroviruses. $J$. Clin. Microbiol., 26, 2576-2580.

9. Chonmaitree, T.; Menegus, M.A.; Powell, K.R. (1982). The clinical relevance of "CSF viral culture": a two-year experience with aseptic meningitis in Rochester, NY. J.A.M.A., 247, 1843-1847.

10. C.V.E. Centro de Vigilância Epidemiológica do Estado de São Paulo. (2005). Meningites: mapas epidemiológicos e gráficos. Available at: http://www.cve.saude.sp.gov.br/htm/cve_meni.htm. Acessed 11 April 2006.

11. Dagan, R.; Menegus, M.A. (1986). A combination of four cell types for rapid detection of enteroviruses in clinical specimens. J. Med. Virol., 19, 219-228.

12. Dagan, R.; Jenistra, J.A.; Menegus, M.A. (1988). Association of clinical presentation, laboratory findings and virus serotypes with the presence of meningitis in hospitalized infants with Enterovirus infection. J. Pediatr., 113, 975-978.

13. Gorgievsky-Hrisoho, M.; Schumacher, J.D.; Vilimonovic, N.; Germann, D.; Maltter, L. (1998). Detection by PCR of enteroviruses in cerebrospinal fluid during a summer outbreak of aseptic meningitis in Switzerland. J. Clin. Microbiol., 36, 2408-2412.

14. Johnston, S.L.; Siegel, C.S. (1990). Presumptive identification of enteroviruses with RD, Hep-2, and RMK cell lines. J. Clin. Microbiol., 28, 1049-1050.

15. Kilpatrick, D.R.; Quay, J.; Pallansch, M.A.; Oberste, M.S. (2001). Type specific detection of echovirus 30 isolates using degenerate reverse transcriptase PCR primers. J. Clin. Microbiol., 39, 12991302.

16. Lamarão, L.M.; Gomes, M.L.C.; Ferreira, L.L.A.; Fonseca, C.M.; Araújo, L.C.B.; Santana, M.B.; Neto, J.T. (2005). Pesquisa de Enterovírus em Casos de síndrome de meningite asséptica de Belém, PA. Rev. Soc. Bras. Med. Trop., 38(5), 391-395.

17. Lim, K.A.; Benyesh-Melnick, M. (1960). Typing of viruses by combination of antiserum pools. Application to typing of enteroviruses (coxsackie and echo). J. Immunol., 84, 309-317.
18. Loon, A.M.V.; Cleator, G.C.; Ras, A. (1999). External quality assessment of Enterovirus detection and typing. European Union Concerted Action on Virus Meningitis and Encephalitis. Bull. W.H.O., 77(3), 217-223.

19. Melnick, J.L.; Wimberly, I.L. (1985). Lyophilized combination pools of Enterovirus equine antisera: new LBM pools prepared from reserves of antisera stored frozen for two decades. Bull. W.H.O., 63, 543-550.

20. Melnick, J.L. (1996). Enteroviruses: poliovirus, coxsackieviruses, echovirus, and newer enteroviruses. In: Fields, B.N.; Knipe, D.M.; Howley, P.M.; Chanock, R.M.; Melnick, J.L.; Monath, T.P.; Roizman, B.; Straus, S.E. (eds). Fields Virology, Third edition. LippincottRaven Publishers. New York, USA, vol. 1, p.655-712.

21. Melnick, J.L.; Wenner, H.A.; Phillips, C.A. (1979). Enteroviruses. In: Lennette E.H.; Schmidt, N.J. eds. Diagnostic procedures for viral and rickettsial diseases. $3^{\text {rd }}$ ed. Washington, D.C.: American Public Health Association, p.471-534.

22. Muir, P.; Kamerer, U.; Korn, K.; Mulders, M.N.; Poyry, T.; Weissbrich, B.; Kandolf, R.; Cleator, G.M.; Loon, A.M.V. for the European Union Concerted Action on Virus Meningitis and Encephalitis. (1998). Molecular typing of enteroviruses: current status and future requirements. Clin. Microbiol. Reviews, 11, 202-227.

23. Oberste, M.S.; Maher, K.; Kilpatrick, D.R.; Flemister, M.R.; Brown, B.A.; Pallansch, M.A. (1999). Typing of human enteroviruses by partial sequencing of VP1. J. Clin. Microbiol., 37, 1288-1293.

24. Oberste, M.S.; Maher, K.; Kilpatrick, D.R.; Pallansch, M.A. (1999). Molecular evolution of the human enteroviruses: correlation of serotype with VP1 sequence and application to picornavirus classification. J. Virol., 73, 1941-1948.

25. Oberste, M.S.; Nix. W.A.; Maher, K.; Pallansch, M.A. (2003). Improved molecular identification of enteroviruses by RT-PCR and amplicon sequencing. J. Clin. Virol., 26, 375-377.

26. Ozkaya, E.; Hizel, K.; Uysal, G.; Akman, S.; Terzioglu, S.; Kuyucu, N. (2003). An outbreak of aseptic meningitis due to echovirus type 30 in two cities of Turkey. Eur. J. Epidemiol., 18, 823-826.

27. Pires, L.V.C.; Carvalhanas, T.R.M.P.; Barbosa, H.A.; Gonçalves, M.I.C.; Timenetsky, M.C.S.T.; Campéas, A.E. (2005). Meningite Viral. CVE - Centro de Vigilância Epidemiológica do Estado de São Paulo. Bol. Epid. Paulista 3 (6), 2006. http://www.cve.saude.sp.gov.br/ $\mathrm{htm} / \mathrm{cve}$ _meni.htm.

28. Reed, L.J.; Muench, H. (1938). A simple method of estimating fifty per cent endpoints. Am. J. Hyg., 27, 493-497.

29. Regenmortel, M.H.V.; Fauget, C.M.; Bishop, D.H.L.; Carstens, E.B.; Estes, M.K.; Lemon, S.M.; Maniloff, J.; Mayo, M.A.; McGeoch, D.J.; Pringle, C.R.; Wicker, R.B. (2000). Virus Taxonomy: The classification and nomenclature of viruses. Seventh Report of the International Committee on Taxonomy of Viruses. Academic Press, San Diego CA.

30. Rotbart, H.A. (1990). Enzymatic RNA amplification of the enteroviruses. J. Clin. Microbiol., 28, 438-442.

31. Rotbart, H.A. (1995). Enteroviral Infections of the central nervous system. Clin. Infect. Dis., 20, 971-981,

32. Santos, G.P.L.; Skraba, I.; Oliveira, D.; Lima, A.A.F. ; Melo, M.M.M.; Knetzch, C.I.; Costa, E.V.; Silva, E.E. (2006). Enterovirus Meningitis in Brazil, 1998-2003. J. Med. Virol., 78, 98-104.

33. Sawyer, M.H.; Holland, D.; Aintablian, N.; Connor, J.D.; Keyser, E.F.; Waecker, N.J. Jr. (1994). Diagnosis of enteroviral central nervous system infection by polymerase chain reaction during a large community outbreak. Ped. Infect. Dis. Journal., 13, 177-182.

34. Strikas, R.A.; Anderson, L.J.; Parker, R.A. (1986). Temporal and geographic patterns of isolates of nonpolio Enterovirus in the United States, 1970-1983. J. Infect. Dis., 153, 346-351.

35. Thoelen, I.; Lemey, P.; Van der Donck, I.; Beuselinck, K.; Lindberg, A.M.; Van Ranst, M. (2003). Molecular Typing and Epidemiology of Enteroviruses Identified From an Outbreak of Aseptic Meningitis in Belgium During the Summer of 2000. J. Med. Virol., 70, 420-429. 
36. Trallero, G.; Casas, I.; Tenorio, A.; Echevarria, J.E.; Castellanos, A.; Lozano, A.; Brena, P.P. (2000). Enteroviruses in Spain: virological and epidemiological studies over 10 years (1988-1997). Epidemiol. Infect., 124, 497-506.

37. Wenner, H.A.; Harmon, P.; Behbehani, A.M.; Rouhandeh, H.; Kamitsuka, P.S. (1967). The antigenic heterogeneity of type 30 echoviruses. Am. J. Epidemiol., 85, 240-249.

38. WHO (World Health Organization). (1990). Manual for the virological investigation of poliomyelitis. W.H.O. Geneva, Switzerland.
39. WHO (World Health Organization). (1998). Aseptic Meningitis due to echovirus 30, Japan, 1997-1998. W.H.O. Weekly Epidemiological Record, Vol. 73, $\mathrm{N}^{\circ} 36$.

40. Yamashita, K.; Myamura, K.; Yamedera, S. (1994). Epidemics of aseptic meningitis due to echovirus 30 in Japan. Jpn. J. Med. Sci Biol., 47, 221-239.

41. Yerly, S.; Gervaix, A.; Simonet, V.; Caflisch, M.; Perrin, L.; Wunderli, W. (1996). Rapid and sensitive detection of enteroviruses in specimens from patients with aseptic meningitis. J. Clin. Microbiol., 34, 199201. 